\title{
FIELD ADAPTATION OF SWEET POTATO GENOTYPES ENRICHED OF $\beta$ - CAROTENE, IN THE STATE OF GOIÁS
}

\author{
ADAPTAÇÃO NO CAMPO DE GENÓTIPOS DE BATATA-DOCE ENRIQUECIDOS \\ DE $\beta$-CAROTENO, NO ESTADO DE GOIÁS
}

\section{Alexandre Igor Azevedo PEREIRA ${ }^{1}$; Lucas Barbosa de FREITAS ${ }^{2}$; Fernando Soares de CANTUÁRIO ${ }^{1}$; Carmen Rosa da Silva CURVÊLO' ${ }^{1}$; Geovani Bernardo AMARO ${ }^{3}$; José Magno Queiroz LUZ}

1. Instituto Federal Goiano-Campus Urutaí. Urutaí, Goiás, Brasil. aiapereira@ yahoo.com.br; 2. Faculdade de Ciências Agronômicas, Universidade Estadual Paulista "Júlio de Mesquita Filho". Botucatu, São Paulo, Brasil; 3. Embrapa Hortaliças. Gama, Distrito Federal, Brasil; 4. Instituto de Ciências Agrárias, Universidade Federal de Uberlândia. Uberlândia, Minas Gerais, Brasil. jmagno@ufu.br

\begin{abstract}
Most sweet potato genotypes marketed in Brazil have white, yellow or cream pulp color with negligible carotenoid contents. The use of beta-carotene rich sweet potato materials may contribute to improve people welfare, especially those at critical nutritional conditions. The yield-related traits and marketable tuber quality of 10 beta-carotene biofortified (or not) sweet potato genotypes were assessed in a Brazilian Cerrado area. Differences for all traits were found, with some materials prevailing. However, four of them (CNPH 1190, CNPH 1206, CNPH 1210 and CNPH 1310) showed good adaptability. CNPH 1210 had the highest yield (52.21 ton $\mathrm{ha}^{-1}$ ), 4.28 times higher than the Brazilian sweet potato average yield. CNPH 1210 and CNPH 1310 had the highest tuber numbers and the most preferred mass class for consumers, and therefore, they furnished the best marketable genotypes. Nevertheless, the materials CNPH 1210 and CNPH 1310 (both orange-fleshed sweet potatoes) stood out for tuber market quality. Our results may stimulate organized civil society efforts to improve the production and consumption of beta-carotene-rich sweet potato materials in municipalities in the Brazilian Cerrado.
\end{abstract}

KEYWORDS: Adaptability. Convolvulaceae. Ipomoea batatas. Nutrition. Provitamin A.

\section{INTRODUCTION}

Sweet potato (Ipomoea batatas L.) (Convolvulaceae) is the fourth most consumed vegetable in Brazil, and the sixth most popular and abundant vegetable in the world (MUSSOLINE; WILKIE, 2016). This plant has relatively low production cost, requires minimal investments in technology, and provides a high financial return. Sweet potato is mainly cultivated by small familiar farmers, such as those located at developing countries, without necessarily using genetically improved varieties (OLIVEIRA et al., 2008). Sweet potato is an important dietary component for populations with food limitation, due to its high nutritional values, including sugars, dietary fibers, vitamins and minerals (SILVA et al., 2010). The leaves have antioxidant activity, suppressing lowdensity lipoprotein oxidation (NAGAI et al., 2011).

Since 2006, Embrapa CNPH (National Center for Vegetable Research) researchers have selected carotenoid-rich (such as $\beta$-carotene) sweet potato materials. This substance is a primary pigment molecule and provitamin A source (MELÉNDEZ-MARTÍNEZ et al., 2007) with high antioxidant capacity by eliminating free radicals, due to conjugated double bonds (FU et al., 2011). This research is part of the Biofortification Project of Embrapa-Biofort (Brazilian Biofortification Program) linked to two international food biofortification programs, the HaverstPlus and the AgroSalud. These programs aim at developing natural foods with nutrient quantities meeting the nutritional needs of the human body (LAURIE et al., 2015). The project also developed rice, beans, corn, cassava, pumpkin and wheat with higher nutrient contents. In 2010, Embrapa CNPH recommended the usage of orange-fleshed sweet potato (Beauregard) in Brazil (variety CNPH 1205, assessed in the present survey), normally used in the United States (VANESBROECK et al., 2008) and registered by the Brazilian Ministry of Agriculture, Livestock and Supply (MAPA, 2016).

In Brazil and Ghana, the most preferred sweet potato varieties have white, yellow or cream flesh (OFORI et al., 2009) with insignificant carotene levels compared to the orange-fleshed ones, with carotene values comparable to those of carrot, the most cited carotene food source (TAKAHATA et al., 1993). Nigerian consumers 
have the same preference (NWANKWO et al., 2014). In China, the four most common sweet potato materials have white, yellow, orange and purple flesh, with different chemical compositions (JUNG et al., 2014).

The use of $\beta$-carotene enriched materials can help population nutrition, especially those in critical nutritional situation. The purpose of the present study was to compare yield traits and tuber quality of $\beta$-carotene biofortified (or not) sweet potato genotypes in a Cerrado Savanna-type environment of Brazil, at Goiás state.

\section{MATERIAL AND METHODS}

The experiment consisted of a completely randomized block design with four replications. The treatments were 10 sweet potato genotypes from Embrapa CNPH, kept in Gama, Distrito Federal, Brazil. Sweet potato genotypes are visually separated by their inner and outside color and leaf morphology (Table 1).

Table 1. Visual characteristics (skin and flesh color) of tubers, and leaf morphology of the 10 sweet potato materials, Ipomoea batatas (Convolvulaceae), cultivated in Urutaí, Goiás state, Brazil, 2013/2014 agricultural year

\begin{tabular}{|c|c|c|c|c|c|c|}
\hline \multirow{2}{*}{$\begin{array}{l}\text { Materials } \\
\text { (CNPH) }\end{array}$} & \multicolumn{3}{|l|}{ Tuber color } & \multicolumn{3}{|l|}{ Leaf shape } \\
\hline & Inside view & Skin & Flesh & General & $\begin{array}{l}\text { Lobes } \\
\text { type }\end{array}$ & $\begin{array}{l}\text { Central lobe } \\
\text { shape }\end{array}$ \\
\hline $1190 *$ & & Purple-red & White & Triangular & $\begin{array}{l}\text { Very } \\
\text { slight }\end{array}$ & Toothed \\
\hline 1195 & & Pinkish & $\begin{array}{l}\text { Intermediate } \\
\text { Orange }\end{array}$ & Lanceolate & Deep & Lanceolate \\
\hline 1205 & & Purple-red & $\begin{array}{l}\text { Intermediate } \\
\text { Orange }\end{array}$ & Lobed & Slight & Triangular \\
\hline $1206^{*}$ & & Cream & White & Lanceolate & Deep & Lanceolate \\
\hline 1210 & & Cream & Dark Orange & Cordate & $\begin{array}{l}\text { Very } \\
\text { slight }\end{array}$ & Toothed \\
\hline 1304 & & Purple-red & Dark Orange & Triangular & $\begin{array}{l}\text { Very } \\
\text { slight }\end{array}$ & Toothed \\
\hline 1310 & & Pinkish & Dark Orange & Triangular & Slight & Toothed \\
\hline 1338 & & Dark purple & Dark Orange & Cordate & $\begin{array}{l}\text { Very } \\
\text { slight }\end{array}$ & Toothed \\
\hline $1340 *$ & & Cream & White & Triangular & $\begin{array}{l}\text { Very } \\
\text { slight }\end{array}$ & Toothed \\
\hline 1362 & & Pinkish & Dark Orange & Cordate & $\begin{array}{l}\text { Very } \\
\text { slight }\end{array}$ & Toothed \\
\hline
\end{tabular}

*Non-biofortified genotypes.

The soil, Red Yellow Dystrophic type, was collected before experiment installation at 0 to 0.20 $\mathrm{m}$ depth, and presented the following characteristics: $\mathrm{pH}$ in water of $6.01 ; \mathrm{Ca}, \mathrm{Mg}, \mathrm{K}, \mathrm{H}+\mathrm{Al}$ of $0.2,1.8$, 0.43 , and $5.8 \mathrm{cmol}_{\mathrm{c}} \mathrm{dm}^{-3}$, respectively; $\mathrm{P}$ of $0.67 \mathrm{mg}$ $\mathrm{dm}^{-3}$; organic matter of $22.2 \mathrm{~g} \mathrm{~kg}^{-1} ; \mathrm{Cu}, \mathrm{Fe}, \mathrm{Mn}$, and $\mathrm{Zn}$ of $4.3,79.1,28.3$, and $4.1 \mathrm{mg} \mathrm{dm}^{-3}$, respectively, and granulometry of 226.2, 209.8, and $564.0 \mathrm{~g} \mathrm{~kg}^{-1}$ of clay, silt and sand, respectively. Soil preparation consisted of forming $30 \mathrm{~cm}$ furrow, spaced $80 \mathrm{~cm}$ apart, by using a bedshaper coupled with a rotary hoe. These beds were separated in half each one, forming the furrows with the dimensions described. 
Field adaptation of sweet potato...

No plowing was required and only a rotary hoe was used to loose soil and weed elimination

The experimentation was held out from November 2015 to April 2016, in a $600 \mathrm{~m}^{2}$ experimental area, and the propagating material consisted of seed-stems (called seedlings) with six to eight internodes (about 30 centimeter). Each plot had five $4 \mathrm{~m}$ furrows, spaced $80 \mathrm{~cm}$ between them, and $33 \mathrm{~cm}$ between plants (three plants per linear meter). Plots were spaced by one meter.

The fertilization consisted of a $60-120-90 \mathrm{~kg}$ $\mathrm{ha}^{-1}$ of $\mathrm{N}, \mathrm{P}_{2} \mathrm{O}_{5}$ and $\mathrm{K}_{2} \mathrm{O}$, respectively, formula with all the phosphorus applied at planting and the $\mathrm{N}$ and $\mathrm{K}_{2} \mathrm{O}$ in portions, half at planting time and half at coverage, when seedlings began to sprout (about four to five weeks after grafting). This fertilization formula meets the nutritional requirements of sweet potato types evaluated (biofortified or not) (PHILLIPS et al., 2005).

Seedlings were manually buried using a 40 $\mathrm{cm}$ plastic sharpened stick. The stem base was deposited into a hole with half of its length buried $(30 \mathrm{~cm})$ and the soil accommodated around the stem. Irrigation was held away by conventional overhead irrigation, and the main cultural treatments to developing sweet potatoes were taken.

The shoot fresh mass (ton ha ${ }^{-1}$ ) (SFM), shoot dry mass (ton ha ${ }^{-1}$ ) (SDM), final tuber numbers $(\mathrm{n} / \mathrm{ha})(\mathrm{FNT})$, yield (ton ha $\left.{ }^{-1}\right)(\mathrm{Y})$, fresh mass $(\mathrm{kg})$ of five commercial tubers (FM5CR) and dry mass $(\mathrm{kg})$ of five commercial tubers (DM5CR) were determined. Seedlings viability (\%) (VIAB) was also measured by the ratio between seedlings planted and surviving plants at harvesting. After harvesting, all tubers were individually categorized according to their mass in seven classes: extra A (between 301 and $400 \mathrm{~g}$ ), extra B (201 and $300 \mathrm{~g}$ ), special (151 and $200 \mathrm{~g})$, miscellaneous I $(80$ and $150 \mathrm{~g})$, miscellaneous II (400 and $800 \mathrm{~g}$ ), discarded I (below $80 \mathrm{~g}$ ) and discarded II (above $800 \mathrm{~g}$ ). This classification is used as standard for tuber commercialization in Brazil, although it is not officially registered.

All data were checked for analysis of variance assumptions. Normality was verified by the Lilliefors test and by visual symmetry of the histogram obtained with the software SAEG (System of Statistical and Genetic Analysis) (RIBEIRO JÚNIOR; MELO, 2008). All yield variables, seedlings viability, and categorization of sweet potato tubers as function of their weight followed normal distribution. After verification of the mean
PEREIRA, A. I. A. et al.

significance (or not) between materials, using ANOVA, sweet potato yield and quality means were compared using the Tukey test at 5\% probability level.

\section{RESULTS}

\section{Shoot mass and seedling viability}

Shoot fresh mass $(\mathrm{F}=15.87, \mathrm{df}=9, P=0.00)$ and shoot dry mass $(\mathrm{F}=8.28, \mathrm{df}=9, P=0.00)$ differed between sweet potato genotypes (Table 2). CNPH 1206 had highest shoot fresh mass, $82.89 \pm$ 2.79 tons ha ${ }^{-1}$ and CNPH 1205 the lowest $(33.19 \pm$ 1.08 ton $\mathrm{ha}^{-1}$ ). The other genotypes had intermediate values: 41.46 ton $\mathrm{ha}^{-1}$ (CNPH 1190) to 54.17 ton ha 1 (CNPH 1340). The shoot dry mass showed a similar response. The materials CNPH 1206 and CNPH 1205 presented the highest $(8.46 \pm 0.26$ ton $\left.\mathrm{ha}^{-1}\right)$ and lowest dry mass $\left(4.82 \pm 0.64\right.$ ton $\left.\mathrm{ha}^{-1}\right)$ values, respectively (Table 2).

Seedlings viability varied between genotypes $(\mathrm{F}=3.89, \mathrm{df}=9, P=0.00)$ (Table 2). A total of $93.05 \%$ of the CNPH 1210 seedlings originated adult plants, while this was $66.66 \%$ for the CNPH 1190 (Table 2). The viability of the remaining materials ranged between $72.22 \%$ and $87.50 \%$.

\section{Tuber yield}

The number of tubers differed between the genotypes evaluated $(\mathrm{F}=67.63, \mathrm{df}=9, P=0.00)$ (Table 3). CNPH 1310 (with the highest tuber numbers) produced 10.67 times more tubers than the CNPH 1340 (with the lowest tuber number) (Table 3). CNPH 1310 yielded about 3.5, 2.6, 1.6, 4.0, 2.3, 3.7, 2.5 and six times more tubers than the $\mathrm{CNPH}$ 1190, CNPH 1195, CNPH 1205, CNPH 1206 CNPH 1210, CNPH 1304, CNPH 1338 and CNPH 1362, respectively.

The material CNPH 1210 had the highest yield, 52.21 ton $\mathrm{ha}^{-1}(\mathrm{~F}=48.89, \mathrm{df}=9, P=0,00)$ (Table 3 ). The yield of the other genotypes ranged between 13.93 ton $\mathrm{ha}^{-1}$ (CNPH 1206) and 47.43 ton $\mathrm{ha}^{-1}$ (CNPH 1205). CNPH 1340 genotype had the lowest yield (7.45 ton ha ${ }^{-1}$ ) (Table 3).

Fresh mass $(\mathrm{F}=5.46, \mathrm{df}=9, P=0.00)$ and dry mass $(\mathrm{F}=8.08, \mathrm{df}=9, P=0.00)$ of five commercial tubers differed between each other (Table 3). CNPH 1310 and CNPH 1210 genotypes produced heavier tubers, while the dry mass of the CNPH 1190 and CNPH 1206 tubers were heavier. 
Table 2. Values (Mean $\pm \mathrm{SE}^{1}$ ) of shoot fresh mass (ton ha ${ }^{-1}$ ), shoot dry mass (ton ha ${ }^{-1}$ ) and seedling viability (\%) of sweet potato genotypes, Ipomoea batatas (L.) (Convolvulaceae), cultivated in Urutaí, Goiás state, Brazil, agricultural year of 2013/2014

\begin{tabular}{llll}
\hline $\begin{array}{l}\text { Materials } \\
(\mathrm{CNPH})\end{array}$ & SFM & SDM & VIAB \\
\hline $1190^{*}$ & $4.46 \pm 5.88 \mathrm{c}$ & $0.51 \pm 0.04 \mathrm{~d}$ & $66.66 \pm 2.15 \mathrm{c}$ \\
1195 & $4.70 \pm 4.13 \mathrm{c}$ & $0.68 \pm 0.04 \mathrm{c}$ & $79.16 \pm 5.59 \mathrm{abc}$ \\
1205 & $3.31 \pm 1.08 \mathrm{e}$ & $0.48 \pm 0.06 \mathrm{~d}$ & $87.50 \pm 4.16 \mathrm{ab}$ \\
$1206^{*}$ & $8.28 \pm 2.79 \mathrm{a}$ & $0.84 \pm 0.02 \mathrm{a}$ & $88.88 \pm 3.51 \mathrm{ab}$ \\
1210 & $4.21 \pm 1.38 \mathrm{c}$ & $0.54 \pm 0.04 \mathrm{~d}$ & $93.05 \pm 3.97 \mathrm{a}$ \\
1304 & $4.29 \pm 3.86 \mathrm{c}$ & $0.63 \pm 0.01 \mathrm{c}$ & $80.55 \pm 1.75 \mathrm{abc}$ \\
1310 & $4.33 \pm 2.67 \mathrm{c}$ & $0.50 \pm 0.03 \mathrm{~d}$ & $77.77 \pm 4.64 \mathrm{abc}$ \\
1338 & $4.95 \pm 5.69 \mathrm{~d}$ & $0.70 \pm 0.02 \mathrm{~b}$ & $72.22 \pm 4.12 \mathrm{bc}$ \\
$1340^{*}$ & $5.41 \pm 1.71 \mathrm{~b}$ & $0.74 \pm 0.01 \mathrm{~b}$ & $83.33 \pm 3.04 \mathrm{abc}$ \\
1362 & $5.96 \pm 5.37 \mathrm{~b}$ & $0.64 \pm 0.06 \mathrm{c}$ & $73.61 \pm 7.27 \mathrm{abc}$ \\
$\mathrm{CV}(\%)$ & 13.74 & 13.07 & 12.03 \\
\hline
\end{tabular}

${ }^{1}$ Means followed by the same letter do not differ at the $5 \%$ probability level by the Tukey test. SFM= shoot fresh mass $\left(\right.$ ton ha $\left.{ }^{-1}\right)$, SDM= shoot dry mass (ton ha ${ }^{-1}$ ), and VIAB = seedlings viability $(\%)$. Non-biofortified genotypes.

Table 3. Final tuber numbers $\left(\mathrm{n} \mathrm{ha}^{-1}\right)(\mathrm{FNT})$, yield $\left(\right.$ ton $\left.\mathrm{ha}^{-1}\right)(\mathrm{Y})$, fresh mass of five commercial tubers $(\mathrm{kg})$ (FM5CT) and dry mass (DM5CT) of five commercial tubers $(\mathrm{mg})$ (mean $\pm \mathrm{SE}^{1}$ ) of sweet potato genotypes, Ipomoea batatas (L.) (Convolvulaceae), cultivated in Urutaí, Goiás state, Brazil, agricultural year of 2013/2014

\begin{tabular}{lllll}
\hline $\begin{array}{l}\text { Materials } \\
(\mathrm{CNPH})\end{array}$ & FNT & Y & FM5CT & DM5CT \\
\hline $1190^{*}$ & $8,694.66 \pm 178.87 \mathrm{~d}$ & $17.78 \pm 0.75 \mathrm{~d}$ & $1,549 \pm 0.01 \mathrm{~b}$ & $0.434 \pm 0.04 \mathrm{a}$ \\
1195 & $8,071.61 \pm 287.24 \mathrm{~d}$ & $35.59 \pm 1.17 \mathrm{c}$ & $1,590 \pm 0.03 \mathrm{~b}$ & $0.381 \pm 0.01 \mathrm{~b}$ \\
1205 & $13,196.61 \pm 417.66 \mathrm{c}$ & $47.43 \pm 1.97 \mathrm{~b}$ & $1,574 \pm 0.04 \mathrm{~b}$ & $0.399 \pm 0.04 \mathrm{~b}$ \\
$1206^{*}$ & $5,078.12 \pm 116.58 \mathrm{e}$ & $13.93 \pm 0.09 \mathrm{e}$ & $1,549 \pm 0.01 \mathrm{~b}$ & $0.436 \pm 0.01 \mathrm{a}$ \\
1210 & $11,930.33 \pm 1,736.25 \mathrm{c}$ & $52.21 \pm 4.88 \mathrm{a}$ & $1,624 \pm 0.01 \mathrm{a}$ & $0.318 \pm 0.01 \mathrm{~d}$ \\
1304 & $7,591.14 \pm 633.30 \mathrm{e}$ & $39.02 \pm 2.81 \mathrm{c}$ & $1,578 \pm 0.02 \mathrm{~b}$ & $0.358 \pm 0.05 \mathrm{c}$ \\
1310 & $30,517.57 \pm 1,799.39 \mathrm{a}$ & $32.81 \pm 1.88 \mathrm{c}$ & $1,637 \pm 0.04 \mathrm{a}$ & $0.239 \pm 0.02 \mathrm{~g}$ \\
1338 & $19,059.24 \pm 1,489.20 \mathrm{~b}$ & $32.74 \pm 2.66 \mathrm{c}$ & $1,495 \pm 0.03 \mathrm{c}$ & $0.261 \pm 0.16 \mathrm{f}$ \\
$1340^{*}$ & $2,858.07 \pm 254.35 \mathrm{f}$ & $7.45 \pm 0.49 \mathrm{f}$ & $1,473 \pm 0.02 \mathrm{c}$ & $0.309 \pm 0.09 \mathrm{e}$ \\
1362 & $11,630.85 \pm 621.81 \mathrm{c}$ & $44.13 \pm 1.35 \mathrm{~b}$ & $1,467 \pm 0.03 \mathrm{c}$ & $0.260 \pm 0.01 \mathrm{f}$ \\
\hline $\mathrm{CV}(\%)$ & 16.33 & 13.15 & 3.29 & 15.05
\end{tabular}

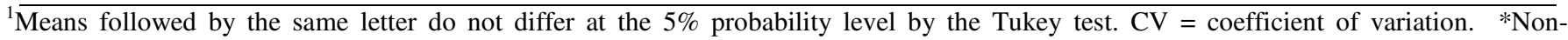
biofortified genotypes.

\section{Qualitative tuber analysis}

The genotypes CNPH 1210 and CNPH 1310 produced larger number of extra A tubers $(\mathrm{F}=15.23$, $\mathrm{df}=9, P=0.00)$ and the CNPH 1340 the lowest number of tubers of this same category (Figure 1A). The CNPH 1210 genotype also produced a larger number of extra $\mathrm{B}(\mathrm{F}=74.52, \mathrm{df}=9, P=0.00)$ (Figure 1B) and especial $(\mathrm{F}=72.25, \mathrm{df}=9, P=0.00)$ (Figure 1C) tubers than the other materials, whereas the genotype CNPH 1340 had low tuber yield of the categories Extra B and Special. The CNPH 1310 had the highest yield of miscellaneous I (Figure 1D) with 1197.91 tubers $(\mathrm{F}=91.46, \mathrm{df}=9, P=0.00)$. The genotypes CNPH 1210 and CNPH 1205 had higher yield of miscellaneous II tubers (Figure $1 \mathrm{E}),(\mathrm{F}=$ 21.68, $\mathrm{df}=9, P=0.00)$. CNPH 1310 and $\mathrm{CNPH}$ 1362 had the highest yield of discard I ( $\mathrm{F}=47.98$, $\mathrm{df}=9, P=0.00$ ) (Figure 1F) and discard II $(\mathrm{F}=$ 23.11, $\mathrm{df}=9, \quad P=0.00$ ) (Figure $1 \mathrm{G}$ ) tubers, respectively. 

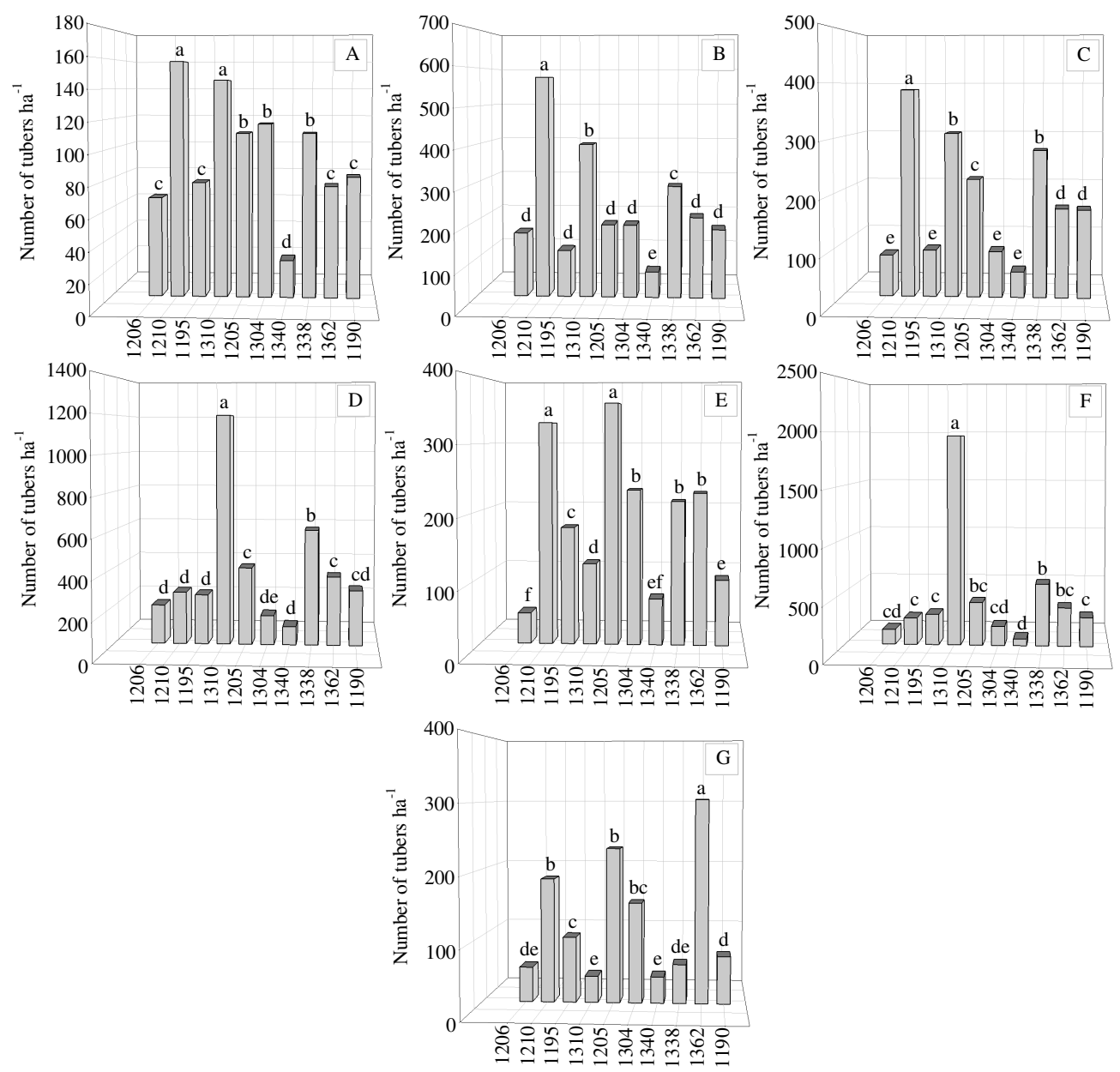

Figure 1. Selection of sweet potato materials, Ipomoea batatas L. (Convovulaceae), with best and worst performances for the characteristics: shoot fresh mass (ton ha ${ }^{-1}$ ) (white bars), shoot dry mass (ton ha ${ }^{-1}$ ) (black bars), seedlings viability (\%) (gray bars), final number of tubers (red bars), yield (ton ha ${ }^{-1}$ ) (green bars), fresh mass of five commercial tubers (kg) (blue bars), and dry mass of five commercial tubers (kg) (yellow bars). Urutaí, Goiás, Brazil, agricultural year of 2013/2014. The genotypes 1190, 1340 and 1206 are non-biofortified.

\section{DISCUSSION}

In general, clear flesh sweet potato clones have higher shoot weight yield than $\beta$-caroteneenriched ones. Our results are similar to those reported in Umudike, Abia state, Nigeria (NWANKWO et al., 2014). Sweet potato tubers have undoubtedly higher added value for the food industry and in natura consumption, but shoot is important as food for domesticated animals. Sweet potato leaves and stems have high crude protein content and good digestibility for dairy or beef cattle, as fresh leaves and silage (GONÇALVES et al., 2011; VIANA et al., 2011). In Southeast Asia, sweet potato leaves are consumed as vegetables by the population (NAGAI et al., 2011). Tubers with pale yellow or white flesh are more suitable to manufacture flour or feeding domesticated animals, because they are less sweet than those with purple, reddish or orange flesh clones (MUSSOLINE; WILKIE, 2016).

The high viability of the biofortified genotype CNPH 1210 is important, since this study used manual planting system (seed-stems), what is more rustic, and therefore, more susceptible to plant establishment failures. This material can also be studied for clonal seedlings in tissue cultures similar to the potato seedling production system (Solanum tuberosum L.) (Solanaceae) (HOQUE et al., 1996). Besides, the adaptability and resistance of the CNPH 1210 seedlings should be better investigated because sweet potato planting and production system adopted in many countries worldwide is mechanized.

The yield obtained, 7.45 to 52.21 ton $\mathrm{ha}^{-1}$ for genotypes CNPH 1340 and CNPH 1210, 
respectively, differ from the Brazilian average (11.80 ton ha ${ }^{-1}$ ) (IBGE, 2016). The genotype CNPH 1340 had a yield similar to that in Nigeria (7 ton ha ${ }^{1}$ ) (NWANKWO et al., 2014). The CNPH 1210 material reached four times the Brazilian mean yield, highlighting it as a promising material. Biofortified sweet potato varieties have been used for their productive potential, as the Beauregard cultivar, the main $\beta$-carotene-enriched cultivar produced in the United States (PHILLIPS et al., 2005; VANESBROECK et al., 2008). This information differs from the report that carotenebiofortified genotypes had lower yield than nonbiofortified ones in Vale do Jequitinhonha, Minas Gerais state, Brazil (ANDRADE JUNIOR et al., 2009). This demonstrates the importance of considering the adaptation of $\beta$-carotene-enriched sweet potato materials in other Brazilian regions to define a yield criterion for this harvest. However, the highest genotype CNPH 1210 yield can be an important criterion to farmers increasing their cultivation, supply this product to market, and consequently, the consumption of this material by the population.

The tuber numbers can be used to predict the yield potential of a given genotype because a positive correlation between yield and tuber numbers (GASURA et al., 2008; MOTSA et al., 2015). However, the increase in tuber numbers decreases its dry matter content, since the plant may not obtain photoassimilates necessary for all tubers to gain mass. In such cases, the production of a few standard size tubers is preferred instead of many low mass tubers.

In Brazil, for example, no official commercial standard has been established for sweet potato, but the existing classification system considers the demands of large consumer markets (Rio de Janeiro and São Paulo) with tuber mass as a reference. In general, Brazilian consumers prefer smooth and elongated sweet potato tubers, and do not appreciate very large or very small ones. The average preference indicates 12 to $16 \mathrm{~cm}$ long, 5 to $8 \mathrm{~cm}$ in diameter, and 200 to $400 \mathrm{~g}$ of tuber fresh mass. At purchase, the visual aspects influence selecting this product, and the decision on buying fruits and vegetables is based on their appearance (ABBOTT et al., 2015). The materials CNPH 1205, CNPH 1210, CNPH 1310, and CNPH 1362 had high tuber yield classified as miscellaneous and discard. However, these materials can be used for industrial processing because they also present nutritional characteristics of tubers of the commercially desirable classes (CARDOSO et al., 2005). Clones with higher dry mass (such as the non-biofortified genotypes CNPH 1206 and CNPH 1190) have higher sale value for industrial purposes (QUEIROGA et al., 2007).

The Brazilian consumer preference by sweet potatoes with pale flesh and white, pink or purple skin (Filgueira, 2013) has been changed due to the nutritional advantages of $\beta$-carotene-enriched sweet tubers, a substance which benefits humans as a vitamin A precursor (MAIANI et al., 2009). Thus, the consumption of these last sweet potatoes should be encouraged, especially as food for people at nutrition risk in Brazil and other developing countries (SILVA et al., 2010). South African companies, private organizations and human nutrition, public sectors have invested in boosting $\beta$ carotene-enriched sweet potato consumption (LAURIE et al., 2015). This confirms a typical characteristic of sweet potatoes breeding programs in Brazil as found in other tropical regions in the world (VILLAREAL; JO, 1983): the existence of a vast germplasm bank what facilitates finding materials meeting different requirements.

\section{CONCLUSIONS}

The yield and qualitative parameters of $\beta$ carotene-enriched (or not) sweet potato genotypes strongly differed from each other.

The non-biofortified genotype CNPH 1206 (white-fleshed) presented the highest shoot fresh and dry mass yield and the CNPH 1310 and CNPH 1210 (both orange-fleshed) the highest tuber number and yield, respectively. CNPH 1210 also showed high tuber numbers with fresh mass classified with highest value in the Brazilian marketplace.

In pragmatic terms, familiar-based farmers can profit from the cultivation of $\beta$-carotene rich, sweet potato materials because this plant requires management with a depressed degree of technology. Our results may stimulate efforts to improving the production and consumption of $\beta$-carotene rich sweet potato materials in more Brazilian regions, such as those where Brazilian Cerrado Savanna-type environments predominates.

RESUMO: A maioria dos genótipos de batata-doce comercializados no Brasil tem cor de polpa branca, amarela ou creme, com conteúdo desprezível de carotenóides. O uso de materiais de batata-doce ricos em betacaroteno pode contribuir para melhorar o bem-estar das pessoas, especialmente aquelas em condições 
nutricionais críticas. Características relacionadas ao rendimento e a qualidade comercial dos tubérculos de 10 genótipos de batata-doce biofortificada (ou não) com beta-caroteno foram avaliadas em uma área do Cerrado brasileiro. Diferenças para todas as características foram encontradas, com alguns materiais predominantes. No entanto, quatro deles (CNPH 1190, CNPH 1206, CNPH 1210 e CNPH 1310) mostraram boa adaptabilidade. O CNPH 1210 teve o maior rendimento $\left(52,21\right.$ ton $\left.\mathrm{ha}^{-1}\right), 4,28$ vezes maior que o rendimento nacional médio da batata-doce brasileira. CNPH 1210 e CNPH 1310 tiveram o maior número de tubérculos e a classe de massa mais preferida para os consumidores e, portanto, forneceram os melhores genótipos comercializáveis. No entanto, os materiais CNPH 1210 e CNPH 1310 (ambos batata-doce de polpa alaranjada) destacaram-se pela qualidade dos tubérculos comerciais. Nossos resultados podem estimular esforços da sociedade civil organizada para melhorar a produção e consumo de materiais de batata-doce ricos em beta-caroteno em municípios contidos no Cerrado brasileiro.

PALAVRAS-CHAVE: Adaptabilidade. Convolvulaceae. Ipomoea batatas. Nutrição. Provitamina A.

\section{REFERENCES}

ABBOTT, J. A. Quality measurement of fruits and vegetables. Postharvest Biology and Technology, v. 15, n. 3, p. 207-225, Mar. 1999. https://doi.org/10.1016/s0925-5214(98)00086-6

ANDRADE JUNIOR, V. C.; VIANA, D. J. S.; FERNANDES, J. S. C.; FIGUEIREDO, J. A.; NUNES, U. R.; NEIVA, I. P. Selection of sweet potato clones for the region Alto Vale do Jequitinhonha. Horticultura Brasileira, Brasília, v. 27, n. 3, p. 389-393, Sep. 2009. https://doi.org/10.1590/s0102-05362009000300024

CARDOSO, A. D.; VIANA, A. E. S.; RAMOS, P. A. S.; MATSUMOTO, S. N.; AMARAL, C. L. F.; SEDIYAMA, T.; MORAIS, O. M. Avaliação de clones de batata-doce em Vitória da Conquista. Horticultura Brasileira, Brasília, v. 23, n. 4, p. 911-914, Out-Dec. 2005. https://doi.org/10.1590/s0102-05362005000400009

FILGUEIRA, F. A. R. Novo Manual de Olericultura: agrotecnologia moderna na produção e comercialização de hortaliças. 3. ed. Viçosa: Editora UFV, 2013. 421 p.

FU, H.; XIE, B.; MA, S.; ZHU, X.; FAN, G.; PAN, S. Evaluation of antioxidant activities of principal carotenoids available in water spinach (Ipomoea aquatica). Journal of Food Composition and Analysis, San Diego, v. 24, n. 2, p. 288-297, Mar. 2011. https://doi.org/10.1016/j.jfca.2010.08.007

GASURA, E.; MASHINGAIDZE, A. B.; MUKASA, S. B. Genetic variability for tuber yield, quality, and virus disease complex traits in Uganda sweetpotato germplasm. African Crop Science Journal, Kampala, v. 16, n. 2, p. 147-160, 2008. https://doi.org/10.4314/acsj.v16i2.54355

GONÇALVES NETO, A. C.; MALUF, W. R.; GOMES, L. A. A.; GONÇALVES, R. J. S.; SILVA, V. F.; LASMAR, A. Aptidões de genótipos de batata-doce para consumo humano, produção de etanol e alimentação animal. Pesquisa Agropecuária Brasileira, Brasília, v. 46, n. 11, p. 1513-1520, Nov. 2011. https://doi.org/10.1590/s0100-204x2011001100013

HOQUE, M. I.; MILA, N. B.; KHAN, M. D. S.; SARKAR, R. H. Shoot regeneration and in vitro microtuber formation in potato (Solanum tuberosum L.). Bangladesh Journal of Botany, Dhaka, v. 25, n. 1, p. 87-93, Jun. 1996.

IBGE. Área plantada, área colhida, quantidade produzida e valor da produção da batata-doce. 2016. Available in: http://www.sidra.ibge.gov.br. Accessed in: 10 dec. 2016. 
JUNG, S. B.; SHIN, J. H.; KIM, J. Y.; KWON, O. Shinzami Korean purple-fleshed sweet potato extract prevents ischaemia-reperfusion-induced liver damage in rats. Journal of the Science of Food and Agriculture, Oxford, v. 95, n. 14, p. 2818-2823, Dec. 2014. https://doi.org/10.1002/jsfa.7021

LAURIE, S.; FABER, M.; ADEBOLA, P.; BELETE, A. Biofortification of sweet potato for food and nutrition security in South Africa. Food Research International, Essex, v. 76, n. 4, p. 962-970, Oct. 2015. https://doi.org/10.1016/j.foodres.2015.06.001

MAIANI, G.; PERIAGO, C. M. J.; CATASTA, G.; TOTI, E.; GOÑI, C. I.; BYSTED, A.; GRANADOLORENCIO, F.; OLMEDILLA-ALONSO, B.; KNUTHSEN, P.; VALOTI, M.; BÖHM, V.; MAYERMIEBACH, E.; BEHSNILIAN, D.; SCHLEMMER, U. Carotenoids: actual knowledge on food sources, intakes, stability and bioavailability and their protective role in humans. Molecular Nutrition \& Food Research, Weinheim, v. 53, n. 2, p. 194-218, sep. 2009. https://doi.org/10.1002/mnfr.200800053

MAPA. Cultivares de batata-doce registradas. 2016. Available in: http://extranet.agricultura. gov.br/php/snpc/cultivarweb/cultivares_registradas.php. Accessed in: 03 dec. 2016.

MELÉNDEZ-MARTÍNEZ, A. J.; ESCUDERO-GILETE, M. L.; VICARIO, I. M.; HEREDIA, F. J. Relationship between the color and the chemical structure of carotenoid pigments. Food Chemistry, Barking, v. 101, n. 3, p. 1145-1150, 2007. https://doi.org/10.1016/j.foodchem.2006.03.015

MOTSA, N. M.; MODI, A. T.; MABHAUDHI, T. Sweet potato (Ipomoea batatas L.) as a drought tolerant and food security crop. South African Journal of Science, Cape Town, v. 111, n. 11-12, p. 1-8, 2015.

https://doi.org/10.17159/sajs.2015/20140252

MUSSOLINE, W. A.; WILKIE, A. C. Feed and fuel: the dual-purpose advantage of an industrial sweetpotato. Journal of the Science of Food and Agriculture, Oxford, v. 97, n. 5, p. 1567-1575, 2016. https://doi.org/10.1002/jsfa.7902

NAGAI, M.; TANI, M.; KISHIMOTO, Y.; IIZUKA, M.; SAITA, E.; TOYOZAKI, M.; KAMIYA, T.; IKEGUCHI, M.; KONDO, K. Sweet potato (Ipomoea batatas L.) leaves suppressed oxidation of low density lipoprotein (LDL) in vitro and in human subjects. Journal of Clinical Biochemistry and Nutrition, Mitakecho, v. 48, n. 3, p. 203-208, 2011. https://doi.org/10.3164/jcbn.10-84

NWANKWO, I. I. M.; BASSEY, E. E.; AFUAPE, S. O. Yield evaluation of open pollinated sweet potato (Ipomoea batatas (L) Lam) genotypes in humid environment of Umudike, Nigeria. Global Journal of Biology, Agriculture \& Health Sciences, v. 3, n. 1, p. 199-204, Jan-Mar. 2014.

OFORI, G.; ODURO, I.; ELLIS, W. O.; DAPAAH, K. H. Assessment of vitamin A content and sensory attributes of new sweet potato (Ipomoea batatas) genotypes in Ghana. African Journal of Food Science, v. 3, n. 7, p. 184-192, 2009.

OLIVEIRA, M. K. T.; BEZERRA NETO, F.; CÂMARA, F. A.; DOMBROSKI, J. L. D.; FREITAS, R. M. O. Multiplicação in vitro de batata-doce (Ipomoea batatas Lam.). Revista Caatinga, Mossoró, v. 21, n. 4, p. 129$134,2008$.

PHILLIPS, S. B.; WARREN, J. G.; MULLINS, G. L. Nitrogen rate and application timing affect 'Beauregard' sweetpotato yield and quality. HortScience, St. Joseph, v. 40, n. 1, p. 214-217, Feb. 2005.

QUEIROGA, R. C. F.; SANTOS, M. A.; MENEZES, M. A.; VIEIRA, C. P. G.; SILVA, M. C. Fisiologia e produção de cultivares de batata-doce em função da época de colheita. Horticultura Brasileira, Brasília, v. 25, n. 3, p. 371-374, Jul-Sep. 2007. https://doi.org/10.1590/s0102-05362007000300010

RIBEIRO JÚNIOR, J. I.; MELO, A. L. P. Guia prático para utilização do SAEG. Viçosa: Folha Artes Gráficas Ltda, 2008. 288 p. 
SILVA, J. B. C.; MELO, W. F.; BUSO, J. A.; NUTTI, M. R.; CARVALHO, P. G. B.; CARVALHO, J. L. V.; NUNES, M. U. C.; FARIAS, A. Beauregard: cultivar testada e indicada de batata-doce. Brasília: Embrapa Hortaliças, 2010.

TAKAHATA, Y.; NODA, T.; NAGATA, T. HPLC determination of ß-carotene of sweetpotato cultivars and its relationship with colour values. Japanese Journal of Breeding, Tokyo, v. 43, n. 3, p. 421-427, 1993.

https://doi.org/10.1270/jsbbs1951.43.421

VANESBROECK, Z.; HOLMES, G. J.; LITTLE, B. E.; THORNTON, A. C.; TRUONG, V. 'Covington' sweetpotato. HortScience, St. Joseph, v. 43, n. 6, p. 1911-1914, Oct. 2008.

https://doi.org/10.21273/hortsci.43.6.1911

VIANA, D. F. S.; ANDRADE JÚNIOR, V. C.; RIBEIRO, K. G.; PINTO, N. A. V. D.; NEIVA, I. P.;

FIGUEIREDO, J. A.; LEMOS, V. T.; PEDROSA, C. E.; AZEVEDO, A. M. Potencial de silagens de ramas de batata-doce para alimentação animal. Ciência Rural, Santa Maria, v. 41, n. 8, p. 1466-1471, Aug.

2011. https://doi.org/10.1590/s0103-84782011000800027

VILLAREAL, R. L.; LO, H. F. Utilization of sweet potato germplasm by plant breeders. Philippines Journal of Crop Science, Laguna, v. 8, n. 3, p. 113-118, 1983. 